\title{
A Histological Study on the Skin of Hyla savignyi (Anura: Hylidae)
}

\author{
Esra AKAT*, Hüseyin ARIKAN \\ Department of Biology, Faculty of Science, Ege University, Izmir, Turkey
}

\begin{abstract}
Received: 05.11 .2018
Accepted: 05.12 .2018

Published online: 10.12 .2018

Issue published: 28.12 .2018

Abstract: Integument is a prominent defense line and is one of the organs for communication and contact with the external environment. The current study was designed to assess the histomorphological characteristics of the skin of Hyla savignyi. The ventral and dorsal skins of $H$. savignyi were composed of a stratified squamous epithelium and dermis like that of any other vertebrate. The dermis was made up of spongious dermis and compact dermis. In both ventral and dorsal integument samples, two types of cutaneous glands (granular, mucous) were identified. The lumen of granular glands was filled with secretory granules that showed strong acidophilic reaction. Mucous glands were lined by mucocytes and had an obvious lumen. Histomorphological characteristics of the skin did not show any individual variation.

Keywords: amphibian, skin, granular gland, mucous gland, Hyla.

\section{Hyla savignyi (Anura: Hylidae) Derisi Üzerine Histolojik Bir Çalışma}

Öz: Deri önemli bir savunma hattıdır ve dış çevre ile iletişim kuran ve temasta olan bir organdır. Mevcut çalışma Hyla savignyi derisinin histomorfolojik karakterlerinin değerlendirilmesi için planlandı. $H$. savignyi dorsal ve ventral derileri tıpkı diğer omurgalılarda olduğu gibi çok katlı yassı epitel ve dermisten oluştu. Dermis, süngerimsi dermis ve kompakt dermisten oluştu. Hem dorsal hem de ventral deri örneklerinde iki tip dermal bez (granüler, mukoz bezler) tespit edildi. Granüler bezlerin lümeni güçlü asidofilik reaksiyon veren salgı granülleri ile doluydu. Mukoz bezler mukositler ile kaplıydı ve mukoz bezlerin belirgin bir lümeni vardı. Derinin histomorfolojik özellikleri bireysel varyasyon göstermedi.
\end{abstract}

Anahtar kelimeler: amfibi, deri, granüler bez, mukoz bez, Hyla

\section{Introduction}

The integument is a protective barrier between the organism and the environment and it is the first organ to come into contact with pollutants and pathogens. Amphibian skin is a prominent organ that serves critical functions including respiration, water regulation, and defense against predators and microorganisms (Schadich, 2009; Haslam et al., 2014).

The cutaneous of the amphibian comprises of epidermis and dermis like that of any other vertebrate. The epidermis is composed of epithelial cell layers, and the dermis is made up of two layers known as spongious dermis and compact dermis. Stratum spongiosum contains skin glands, blood vessels, and pigment cells and the compact dermis consists of densely packed collagen fibre bundles (Duellman \& Trueb, 1994; Felsemburgh, de Almeida, de Carvalho-e-Silva, \& de Brito-Gitirana, 2009; Akat \& Arıkan, 2013; Akat, Arikan, \& Göçmen, 2014).

Hylidae is a big family of anurans and has a global distribution including 990 known species (AmphibiaWeb, 2018). The dorsal skin of Hyla savignyi is smooth and ventral skin is granular. The color of dorsal skin changes from green to light grey due to temperature and substrate color. The color of ventral skin is white or yellowish. Dorsal region is separated from ventral by thin, dark, and uninterrupted band with outer white edging without an inguinal loop. Fingers of $H$. savignyi have terminal disc (Budak \& Göçmen, 2008).
The aim of the current study was to evaluate the histomorphological characteristics of the skin of $H$. savignyi.

\section{Material and Methods}

The Institutional Animal Ethical Committee, Faculty of Medicine, Ege University (2014-094) and Republic of Turkey Ministry of Forestry and Water Affairs (20 February 2015/43000) approved the current study. Adult specimens of $H$. savignyi (five males, five females) were captured from Samandağ, Hatay/Turkey $\left(36.115757^{\circ} \mathrm{N}\right.$, $\left.35.936653^{\circ} \mathrm{E}\right)$. Amphibians were anesthetized and then euthanized by decapitation. Tissue samples were fixed in Bouin's fluid. After dehydration with graded ethanol $(70 \%-100 \%)$, skin samples were put in xylol for transparency and embedded in paraffin. Paraffin sections were cleared in xylene and rehydrated in graded ethanol (100\%-70\%). Five-micrometer-thickness sections were stained with Gill's haematoxylin-eosin (H-E), Alcian blue (AB) and Periodic acid-Schiff (PAS). Sections were photographed by Zeiss Axioscope light microscope connected to an AxioCam Erc5S digital camera.

\section{Results}

The ventral and dorsal skins of $H$. savignyi were composed of epidermis and dermis. The epidermis of $H$. savignyi consisted of a stratified squamous epithelium with weak keratinization (Fig. A). The dermis was made up of spongious dermis and compact dermis formed by densely 


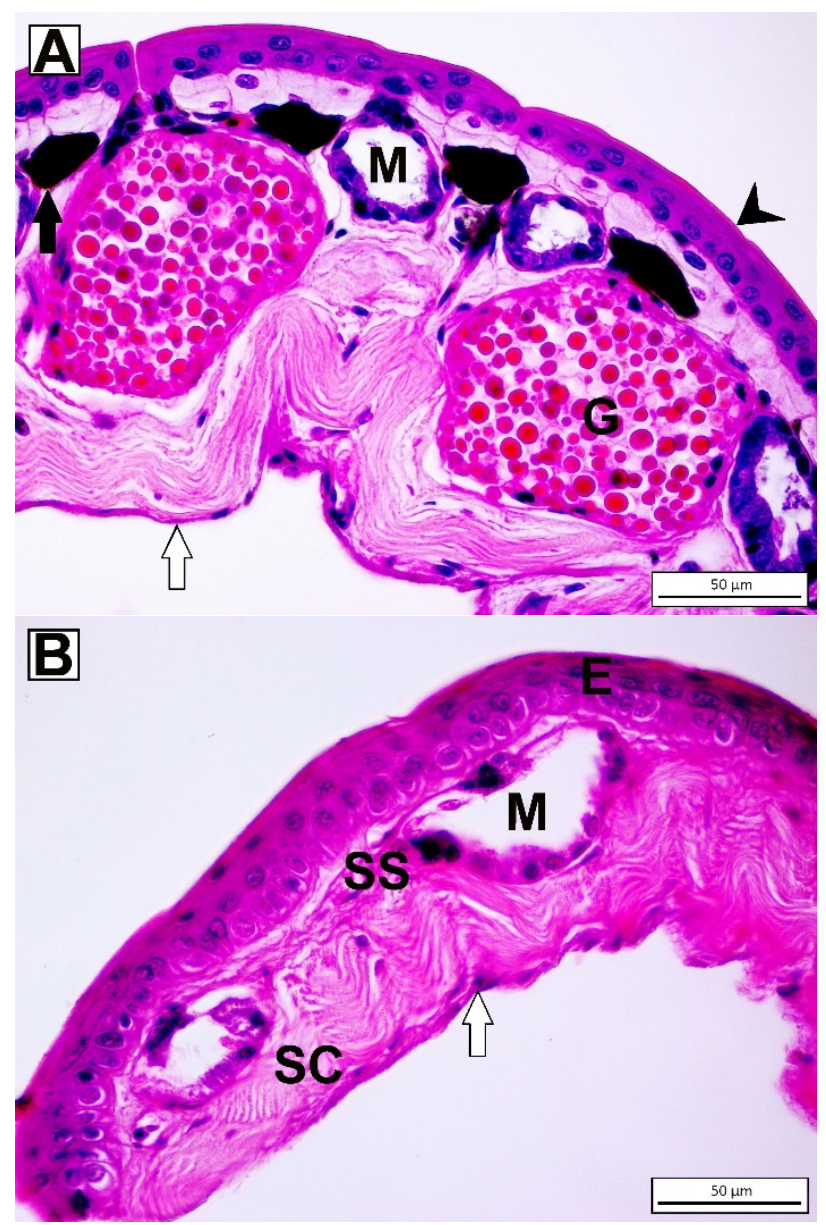

Figure: Light micrograph of the skin of $H$. savignyi, H-E staining. A: The dorsal skin of H. savignyi. Mucous gland (M), granular gland $(G)$ weak keratinization (arrow head), melanin-containing cell (black arrow), tela subcutanea (white arrow) B: The ventral skin of $H$. savignyi, stratum spongiosum (SS), stratum compactum $(\mathrm{SC})$, epidermis $(\mathrm{E})$, mucous gland $(\mathrm{M})$, tela subcutanea (white arrow).

packed collagen fibre bundles (Fig. B). Dorsal and ventral skin ended up tela subcutanea (Fig. A, B).Two distinct types of exocrine glands, granular and mucous, were observed (Fig. A). Cutaneous glands were located in the stratum spongiosum having a connection to the surface of integument by an epidermal duct. The periphery of dermal gland was lined by a monolayer of myoepithelial cells. Mucous glands were lined by mucocytes and had an obvious lumen. Mucous glands of $\mathrm{H}$. savignyi were not stained with PAS and AB. Granular glands were larger than the mucous glands. The lumen of granular glands was filled with secretory granules that showed strong acidophilic reaction (Fig. A). Dermal glands presented same histomorphological features in both dorsal and ventral skins. Melanin-containing cells were localized in the dermis beneath the epidermis of dorsal integument (Fig. A). However, they were not observed in the ventral side due to the fact that the color of the ventral skin is white or yellowish (Fig. B). Histomorphological characteristics of the skin did not show any individual variation.

\section{Discussion}

Due to the fact that amphibians are the study model for many biological processes (Feder, 1992), research related to the biology of amphibians encompasses many fields such as morphology, histology, embryology, ecology, endocrinology, genetics and public health.
The skin was composed of epidermis and dermis like that of any other vertebrate. The skin of $H$. savignyi was similar to other anurans in terms of the main structure of the skin and the localization of cutaneous glands in stratum spongiosum (Felsemburgh, de Almeida, de Carvalho-e-Silva, \& de Brito-Gitirana, 2009; Akat et al., 2014; Andrade, Elías, Grandez, \& Mamani, 2018). The epidermis was a stratified squamous epithelium in $H$. savignyi. The outer limit of epidermis exhibited weak keratinization. In Phyllobates bicolor (Moreno-Gómez, Duque, Fierro, Arango, Peckham, \& Asencio-Santofimio, 2014), the epidermis was composed of lightly keratinized squamous epithelium in contrast to the keratinized epidermis reported for Rhinella granulosa (Chammas, Carneiro, Ferro, Antoniazzi, \& Jared, 2015). The role of the epidermal keratin is to protect the tissue from mechanical friction (Gu \& Coulombe, 2007). The epithelial keratinization degree demonstrates animal adaptation to the terrestrial environment.

Amphibian skin is characterized by having numerous dermal glands. Two distinct types of gland, granular and mucous, were observed in dorsal and ventral skin samples. Corroborating our results, Chammas, Carneiro, Ferro, Antoniazzi, and Jared (2015) reported granular and mucous glands in R. granulosa, and LenziMattos, Antoniazzi, Haddad, Tambourgi, Rodrigues, and Jared (2005) indicated granular and mucous glands in Physalaemus nattereri. On the other hand, other authors (Hippe, Propper, \& Staub, 2014; Rota, Tanteri, Montori, Giachi, Delfino, \& Sever, 2017) noted distinct types of cutaneous glands as lipid and seromucous glands. Nosi, Terreni, Alvarez and Delfino (2002) reported lipid gland in Phyllomedusa hypochondrialis azurea (Hylidae) and Warburg, Rosenberg, Roberts and Heatwole (2000) also noted lipid gland in Litoria caerulea (Hylidae). The presence of different types of glands among distinct genera of arboreal amphibians probably indicates evolutionary convergence for dehydration stress (Barbeau \& Lillywhite, 2005).

$\mathrm{H}-\mathrm{E}$ staining method demonstrated that granular glands showed positive acidophilic reaction. In other words, the secretion of granular glands contained a proteinaceous component. Granular glands of $H$. savignyi probably participate in bacteriostatic effect. It was reported that amphibian skin secretion included biologically active molecules such as biogenic amines, alkaloids, and peptides (Erspamer, 1994; Daly, Spande \& Garraffo, 2005).

Mucus is composed of water and mucins (Neutra \& Forstner, 1987). Mucins are high molecular weight glycoproteins and secreted by epithelial cells (Schumacher, Duku, Katoh, Jörns, \& Krause, 2004). Mucus secretion participates in maintaining tissue moisture and lubricating the reduction in mechanical friction (Lagow, DeSouza, \& Carson, 1999). The carbohydrate content of mucous glands in Lyciasalamandra billae and Lyciasalamandra luschani basoglui was demonstrated by a positive reaction to $\mathrm{AB}$ and PAS methods revealing acidic and neutral mucopolysaccharides (Akat et al., 2014). Generally, carbohydrates have allergic properties (Paschinger, Fabini, Schuster, Rendic, \& Wilson, 2005). Therefore mucus secretions released from mucous glands also contribute to defense activity of the skin. However, mucous glands of $H$. savignyi did not show any positive reaction to $\mathrm{AB}$ and PAS. It was probably related to the 
presence of the numerous granular glands, especially in the dorsal side. Mucous glands in H. savignyi may only serve for mainly skin moisture.

Consequently, this is the first report that provides evidence of histological and histochemical characteristics of the skin of $H$. savignyi. These histological and histochemical characteristics of skin and cutaneous glands may be considered as prominent characters for a taxonomic study. These features also provide information related to their habitat type.

Acknowledgments: This study is a part of the first author's $\mathrm{PhD}$ thesis which was supported by TUBITAK-BIDEB-2211 scholarship program and Ege University Research Council 2012 Grant No. Fen 011.

\section{References}

Akat, E., \& Arıkan, H. (2013). Morphology and biometric study of skin of Hyla orientalis Bedriaga, 1890 (Anura, Hylidae). Russian Journal of Herpetology, 20(4), 253-258.

Akat, E., Arikan, H., \& Göçmen, B. (2014). Investigation of dorsal/ventral skin and the parotoid region of Lyciasalamandra billae and Lyciasalamandra luschani basoglui (Urodela: Salamandridae). Biologia, 69(3), 389-394.

AmphibiaWeb. (2018). Information on amphibian biology and conservation [web application]. AmphibiaWeb, Berkeley, CA, USA. Accessed on: 25.09.18. Available from: http://amphibiaweb.org/

Andrade, P., Elías, P., Grandez, R., \& Mamani, P. (2018). Histological description of the skin of the Titicaca water frog (Telmatobius culeus). Revista de Investigaciones Veterinarias del Perú, 29(1), 64-74.

Barbeau, T.R., \& Lillywhite, H.B. (2005). Body wiping behaviors associated with cutaneous lipids in hylid tree frogs of Florida. Journal of Experimental Biology, 208(11), 2147-2156.

Budak, A., \& Göçmen, B. (2008) Herpetoloji (Herpetology). 2nd ed. Ege University Press, Izmir No.194, pp. 56-68.

Chammas, S.M., Carneiro, S.M., Ferro, R.S., Antoniazzi, M.M., \& Jared, C. (2015). Development of integument and cutaneous glands in larval, juvenile and adult toads (Rhinella granulosa): a morphological and morphometric study. Acta Zoologica, 96(4), 460-477.

Daly, J.W., Spande, T.F., \& Garraffo, H.M. (2005). Alkaloids from amphibian skin: a tabulation of over eight-hundred compounds. Journal of Natural Product, 68(10), 1556-1575.

Duellman, W.E., \& Trueb, L. (1994). Biology of Amphibians. Johns Hopkins University Ltd, London.

Erspamer V. (1994). Bioactive secretions of the amphibian integument, in: Heatwole $\mathrm{H}$, editor. Amphibian biology volume 1: The integument. Chipping Norton: Surrey Beatty and Sons, pp. 178-350.

Feder, M.E. (1992). A perspective on environmental physiology of the amphibians, in: Feder, ME, Burggren, WW. (Eds), Environmental Physiology of the Amphibians. The University of Chicago Press, Chicago, pp. 1-6.

Felsemburgh, F.A., de Almeida, P.G., de Carvalho-e-Silva, S.P., \& de BritoGitirana, L. (2009). Microscopical methods promote the understanding of the integument biology of Rhinella ornata. Micron, 40(2), 198-205.

$\mathrm{Gu}, \mathrm{Li}-\mathrm{H}$, \& Coulombe, P.A. (2007). Keratin function in skin epithelia: a broadening palette with surprising shades. Current Opinion in Cell Biology, 19(1), 13-23.

Haslam, I.S., Roubos, E.W., Mangoni, M.L., Yoshizato, K., Vaudry, H., Kloepper J.E. Pattwell D.M., Maderson P.F., \& Paus R. (2014). From frog integument to human skin: dermatological perspectives from frog skin biology. Biological Reviews, 89(3), 618- 655.

Hippe, S.R., Propper, C.R., \& Staub N.L. (2014). The presence of sexually dimorphic submandibular glands in Taricha granulosa, the roughskinned newt (Salamandridae). Copeia, 1, 38-43.

Lagow, E., DeSouza, M.M., \& Carson, D.D. (1999). Mammalian reproductive tract mucins. Human Reproduction Update, 5(4), 280-292.

Lenzi-Mattos, R., Antoniazzi, M.M., Haddad, C.F.B., Tambourgi, D.V., Rodrigues, M.T., \& Jared, C. (2005). The inguinal macroglands of the frog Physalaemus nattereri (Leptodactylidae): structure, toxic secretion and relationship with deimatic behaviour. Journal of Zoology, 266(4), 385394.

Moreno-Gómez, F., Duque, T., Fierro, L., Arango, J., Peckham, X., \& Asencio-Santofimio, H. (2014). Histological Description of the Skin Glands of Phyllobates bicolor (Anura: Dendrobatidae) Using Three Staining Techniques," International Journal of Morphology, 32(3), 882-888.
Neutra, M.R., \& Forstner, J.F. (1987). Gastrointestinal mucus: synthesis, secretion and function", in: LR Johnson (ed.), Physiology of the gastrointestinal tract, 2nd ed. Raven Press, New York, pp. 975-1009.

Nosi, D., Terreni, A., Alvarez, B., \& Delfino, G. (2002). Serous gland polymorphism in the skin of Phyllomedusa hypochondrialis azurea (Anura, Hylidae): response by different gland types to norepinephrine stimulation. Zoomorphology, 121(3), 139-148.

Paschinger, K., Fabini, G., Schuster, D., Rendic, D., \& Wilson I.B. (2005). Definition of immunogenic carbohydrate epitopes. Acta Biochimica Polonica, 52(3), 629-632.

Rota, E., Tanteri, G., Montori, G., Giachi, F., Delfino, G., \& Sever, D.M. (2017). Skin of the Red Eye Tree Frog Agalychnis callidryas (Hylidae, Phyllomedusinae) Contains Lipid Glands of the Type Described in the Genus Phyllomedusa. The Anatomical Record, 300(3), 503-506.

Schadich, E. (2009). Skin peptide activities against opportunistic bacterial pathogens of the African Clawed Frogs (Xenopus laevis) and three Litoria frogs. Journal Herpetology, 43(2), 173-183.

Schumacher, U., Duku, M., Katoh, M., Jörns J., \& Krause W.J. (2004). Histochemical similarities of mucins produced by Brunner's glands and pyloric glands: a comparative study. The Anatomical Record, 278(2), 540550.

Warburg, M.R., Rosenberg, M., Roberts, J.R., \& Heatwole, H. (2000). Cutaneous glands in the Australian hylid Litoria caerulea (Amphibia, Hylidae). Anatomy and Embryology, 201(5), 341-3. 